\title{
A project of developing a knowledge management system
}

\author{
Ante Martinić*, Petra Bago**, Nives Mikelić Preradović**, \\ Goran Glavaš***, Bojana Dalbelo Bašić***, Jan Šnajder*** \\ *KONČAR - Power Plant and Electric Traction Engineering Inc. \\ Fallerovo šetalište 22, 10000 Zagreb, Croatia \\ **Faculty of Humanies and Social Sciences, University of Zagreb \\ Ivana Lučića 3, 10000 Zagreb, Croatia \\ *** Faculty of Electrical Engineering and Computing, University of Zagreb \\ Unska 3, 10000 Zagreb, Croatia \\ ante.martinic@koncar-ket.hr, \{pbago,nmikelic\}@ffzg.hr, \{goran.glavas, \\ bojana.dalbelo,jan.snajder\}@fer.hr
}

\section{Summary}

Knowledge is an essential element of modern business and increasing attention is given to its acquisition, distribution and exploitation in everyday business activities. Therefore, KONČAR launched the development of a knowledge management system for its own demands and initiated a collaboration with the academic community for scientific research purposes and potential broader social significance of the project. With regard to the multidisciplinary nature of knowledge management, an agreement was reached with the University of Zagreb, the Faculty of Humanities and Social Sciences and the Faculty of Electrical Engineering and Computing. The knowledge management system will enable an effective management of all segments of intellectual capital of an organization, resulting in increase in productivity and higher market competitiveness, as well as an increased capability for generating new values for all parties to the agreement.

Keywords: knowledge management system

\section{The purpose of knowledge management}

It is estimated that $80 \%$ of today's economic value comes from intangible resources (Petrick et al., 1999). The knowledge relates to its intangible resources, consisting of resources recorded on information storage media and knowledge possessed by the organizations' employees. The entire knowledge of an organization constitutes its intellectual capital.

Knowledge management can be defined as a set of activities practiced within an organization with a goal to identify, record and apply knowledge, thereby stimulating also the creation of new knowledge. There are two major forms of 
knowledge: (1) explicit - the knowledge that is recorded on some permanent medium, and (2) tacit - the knowledge that can be found in people's minds (Dalikr, 2005). To enable an effective distribution of knowledge, it is necessary to convert as much tacit knowledge as possible into explicit knowledge.

The intellectual capital, i.e., the knowledge relevant to organizations, can be broken down to human, structural and relational capital (Pearse, 2007). The human capital is represented by knowledge and skills of organization's employees. The structural capital includes systems and processes necessary for an efficient performance of organization's goals. The relational capital is represented by connections between the organization and other business entities. The main elements of the intellectual capital are given in Figure 1.

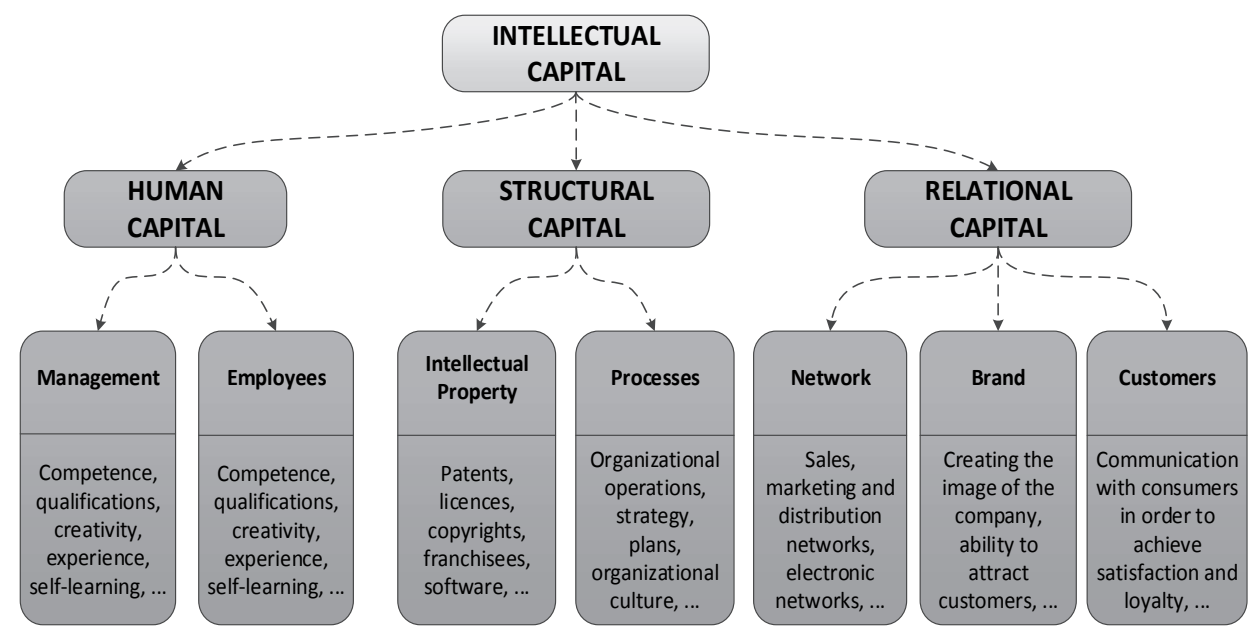

Figure 1. The structure of the intellectual capital (http://autopoiesis.foi.hr/wiki.php?name=KM++ Tim $+50 \&$ parent=NULL\&page $=$ Intelektualni\%20kapital)

\section{Knowledge management at KONČAR Group}

The business activity of the KONČAR Group lies mostly in power generation, distribution and transmission of electrical energy, industry and electric traction. Founded in 1921, KONČAR Group nowadays consists of 18 dependent companies and 1 affiliated company, and has around 3,800 employees. The KONČAR Group builds its business on research activities and production of its products, alongside employing a number of highly educated employees and practicing an individual approach to clients. The companies of the KONČAR Group implement their projects using products that are primarily the result of organization's knowledge and development. In order to manage its own knowledge effectively, KONČAR initiated a project of development and implementation of a 
knowledge management system. The primary objective of this project is to increase the productivity of the KONČAR Group, which can eventually lead to increased market competitiveness and contracting and more effective bidding and implementation of projects. To support a more successful implementation and application of modern technical and scientific achievements, the KONČAR Group initiated an agreement with the University of Zagreb and its constituents - the Faculty of Humanities and Social Sciences and the Faculty of Electrical Engineering and Computing. It is expected that current and future business demands will be met through joint activities, increasing the capability to generate new values for all parties.

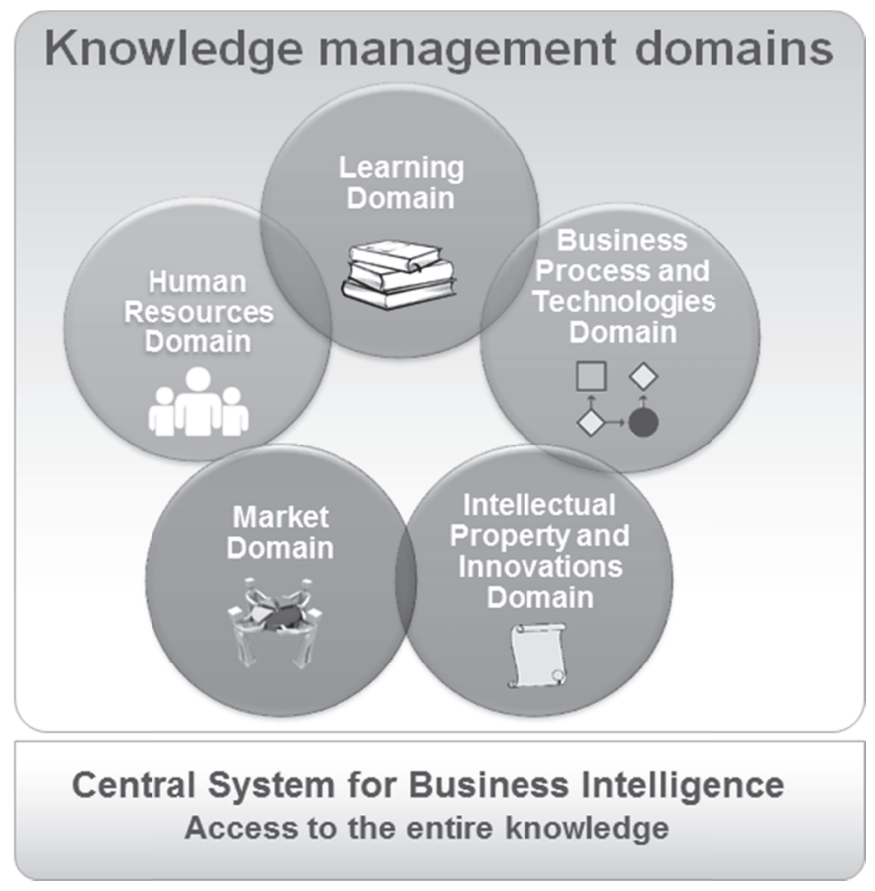

Figure 2. Knowledge management domains

\section{Developing a knowledge management system for the KONČAR Group}

The knowledge management system will encompass all three elements of the intellectual capital: (1) the human capital, (2) the structural capital, and (3) the relational capital. The elements of the intellectual capital of KONČAR's knowledge management system are divided into knowledge management areas as follows:

- Human Resources,

- Learning,

- Natural Language Processing, 
- Business Process and Technologies,

- Intellectual Property and Innovations,

- Market.

In addition to developing knowledge management solutions for all of the abovementioned areas, the project includes construction of the Central System for Business Intelligence which will enable a single-point access to the entire knowledge of the company, i.e., to the knowledge from all six knowledge management areas mentioned above. Each knowledge area encompasses business processes that are implemented through related subprojects.

The relations between elements of the intellectual capital and knowledge management areas are shown in Figure 3.

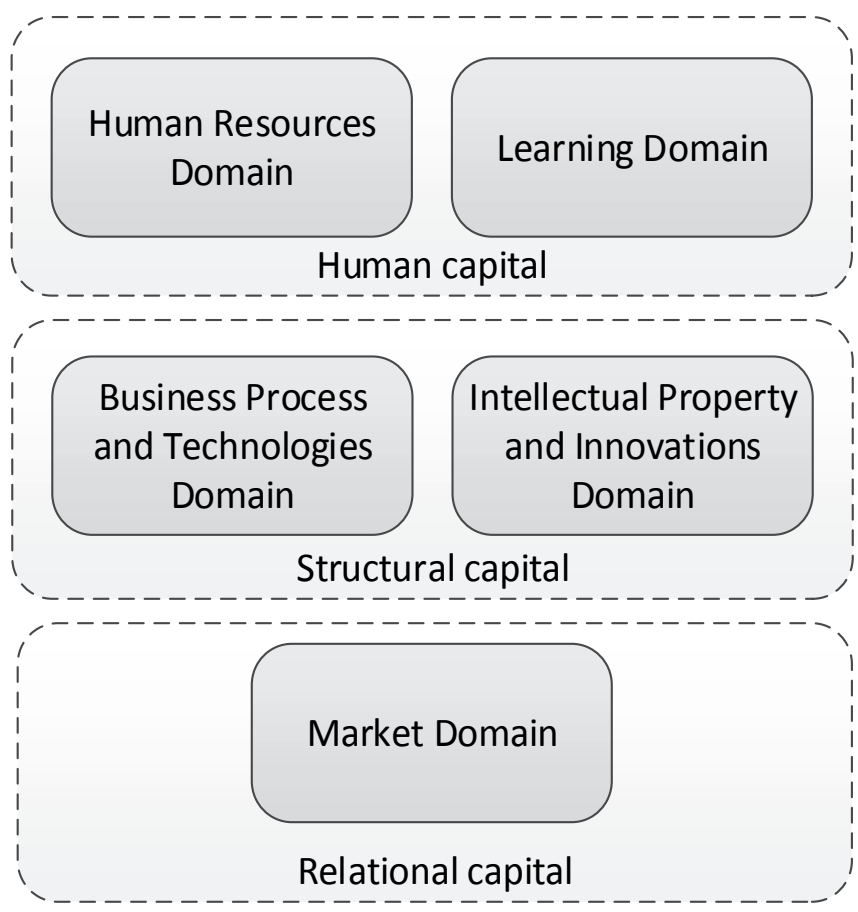

Figure 3. The relation of the elements of the intellectual capital to knowledge management areas

Considering the large scale of the knowledge management system, the iterative approach will be practiced for its development and implementation, which will reduce risks and achieve greater adoption by end users.

Business processes that will be introduced initially are those considered to increase productivity and result in storing a considerable amount of knowledge. Business processes with different stakeholders will be selected for simultaneous 
introduction to various domains of knowledge management. That way the employee workload will be reduced, increasing the opportunity for their active participation, faster adoption of new business processes and related information systems.

In the next section, we examine parts of the project that illustrate the complexity of a large-scale knowledge management system such as the one envisioned by KONČAR. This is an open type project, which means that (apart from the elements listed in the following section), it can likewise include other topics, participants and subprojects.

\section{Collaboration on the development of the knowledge management system}

The scientific community participating in this project includes the University of Zagreb and its two constituents - the Faculty of Humanities and Social Sciences and the Faculty of Electrical Engineering and Computing. These two constituent units represent the leading research institutions in the Republic of Croatia in the areas of social sciences, humanities and technical sciences. These institutions participated in more than 150 international and almost 300 national research projects. The development of challenging and comprehensive company's knowledge management models may additionally position these research institutions as leaders in the higher education domain when it comes to knowledge management, which will further strengthen their status as leading research institutions in Croatia, as well as in the region.

One of the main tasks of the project includes automation of the following processes: collection, transformation and induction of knowledge. Knowledge is derived from information that is precisely formulated in advance, based on the data. The acquisition of existing knowledge is related to the automated (1) collection of information from structured and unstructured (primarily textual) data that the KONČAR Group and similar companies have in abundance, and (2) derivation of knowledge from information by automated reasoning (i.e. machine learning or expert systems). Furthermore, it is necessary to develop a central business intelligence system able to make conclusions based on the information incorporated from structured and unstructured resources.

KONČAR Group and companies of similar technical profile have abundance of unstructured textual data containing crucial business information. Thus, from the technical point of view, it is especially important to focus on the development of methods for efficient text analysis and information extraction from text. Tools for text analysis will significantly contribute to:

1. the management of human resources (automatic analysis of resumes and competencies; linking employees' competencies and projects' requirements);

2. the management of intellectual property and innovations (detecting patentable innovations based on the technical documentation; efficient search of patent databases); 
3. the management of business processes and technology (computer-aided development of company's knowledge base);

4. the knowledge management of the market (automated analysis of tenders; analysis of competitor activity and extraction of relations between entities relevant for company's business activities).

The management of digital resumes of the employees and their competencies is one of the basic tasks of the human resource management. It is necessary to structure and standardize the dynamic digital resumes and automate the process of their loading into the central database. Additionally, we need to identify and analyze the preferences of the employees regarding the specific methods of acquiring knowledge (Coffield et al., 2004) in order to plan and organize the system of educational and training activities, and to develop a taxonomy of the employees' competencies (Jacobs and Washington, 2003). Analyzing employees' competencies and characteristics, it will be possible to optimize job positions, as well as find employees with an optimal profile for a specific job position. In their study, Hilbert \& López (2011) presented the world's technological capacity to store information on analog and digital media in 2007, estimating that $94 \%$ of the stored data was in digital form, while the analog form was represented by only $0.007 \%$. We can assume this ratio in KONČAR Group to be more in favor of the analog form, given that official documents (although mostly digitally born) still need to be printed. However, since the KONČAR Group was founded in 1921, there are also large quantities of documents in paper form. In order to make information from these documents available, these documents must first be digitized (scanned or photographed), i.e., converted from paper form to a form suitable for computer processing (machine-readable text). Next, it is necessary to structure and standardize the digitized documents as well as to annotate them with metadata. Depending on the language contained in the documents, normalization of the text to standard Croatian will be required. For each step in the digitization process, it is necessary to apply existing or develop new (semi)automated methods.

An e-document management system, i.e., a digital archival information system has to be created in order to search and manipulate through large collections of both digitally born and digitized documents. It is necessary to enable the management of e-documents and e-records, to ensure their longevity and to ensure the trust of users in this type of records. Digital signatures will enable the verification of authenticity of digitally born and digitized documents. Furthermore, it is necessary to develop mechanisms of authenticating a printed record which has been digitally signed. All digitized documents will be archived in the central business intelligence system, and thus available for the business intelligence analyses. This will allow historical (mostly unstructured) and new (equally structured and unstructured) data to be interconnected, which will enable derivation of new knowledge and efficient decision-making. 


\section{Conclusion}

The knowledge management project launched by KONČAR aims to develop a knowledge management system for the KONČAR Group's own demands, through collaboration with the academic community with the potential broader social significance of the project. The expertize of the researchers from the Faculty of Humanities and Social Sciences and the Faculty of Electrical Engineering and Computing at the University of Zagreb in the relevant areas, as well as the experience of these institutions in participation and management of international and national projects, will contribute to improving the market position of the KONČAR Group. Finally, this collaboration can help to advance KONČAR Group's own business processes, contribute to joint appearance and to the implementation of the knowledge management solutions in other companies.

\section{References}

Coffield, Frank; Moseley, David; Hall, Elaine; Ecclestone, Kathryn. Learning styles and pedagogy in post 16 learning: a systematic and critical review. The Learning and Skills Research Centre, 2004.

Hilbert, Martin; López, Priscila. The World's Technological Capacity to Store, Communicate, and Compute Information. // Science. 332 (2011), 6025; 60-65.

Jacobs, Ronald; Washington, Christopher. Employee development and organizational performance: a review of literature and directions for future research. // Human Resource Development International. 6(3) (2003), 343-354).KONČAR - Inženjering za energetiku i transport, Program uspostave sustava upravljanja znanjem u Grupi KONČAR, September 2014.

Petrick, Joseph A.; Scherer, Robert F.; Brodzinski, James D.; Quinn, John F.; Ainina, M. Fall. Global leadership skills and reputational capital: Intangible resources for sustainable competitive advantage. // Journal of the Academy of Management Executive. 13(1) (1999), 58-69.

Dalikr, Kimiz. Knowledge Management in Theory and Practice. Burlington: Elsevier, 2005

Pearse, Noel. The Role of Experience in the Creation of Intellectual Capital // Proceedings of ICICKM 2007 The 4th International Conference on Intellectual Capital, Knowledge Management and Organisational Learning / Remenyi Dan (ed.). Cape Town, 2007, 329-335. 